\title{
Analysis of testosterone pulsatility in women with ovulatory menstrual cycles
}

\author{
Análise da pulsatilidade da testosterona em \\ mulheres com ciclos menstruais ovulatórios
}

Lucia H. C. Nóbrega', George D. Azevedo², Josivan G. Lima', Rui A. Ferriani ${ }^{3}$, Poli Mara Spritzer ${ }^{4}$, Marcos F. S. Sáa ${ }^{3}$, Técia M. O. Maranhão²

1 Programa de Pós-graduação em Ciências da Saúde, Universidade Federal do Rio Grande do Norte (UFRN), Natal, RN, Brasil ${ }^{2}$ Programa de Pós-graduação em Ciências da Saúde, Departamentos de Morfologia e Tocoginecologia, UFRN, Natal, RN, Brasil ${ }^{3}$ Departamento de Ginecologia e Obstetrícia, Faculdade de Medicina de Ribeirão Preto (FMRP), Universidade de São Paulo (USP), Ribeirão Preto, SP, Brasil ${ }^{4}$ Departamento de Fisiologia, Universidade Federal do Rio Grande do Sul (UFRGS), Porto Alegre, RS, Brasil

Correspondence to: Lucia H. C. Nóbrega Av. Afonso Pena, 757 59020-100 - Natal, RN, Brasil josivanlima@gmail.com

Received on Mar/9/2009 Accepted on Oct/16/2009

\begin{abstract}
Objective: To evaluate the pattern of the pulsatile secretion of testosterone in normal menstrual cycle. Methods: Eight healthy women with ovulatory menstrual cycles were enrolled. Blood samples were collected at ten-minute intervals for six hours, starting between 7 and $8 \mathrm{am}$, after a ten-hour fasting, in three phases: mid-follicular (Day 7), late follicular (Day 12) and mid-luteal phase (Day 21). Samples were assayed for testosterone, LH and the baseline also for SHBG. Results: Testosterone pulse frequency, mean amplitude pulse, percentage of increment in pulse amplitude, mean duration of pulses and pulse interval were similar in the three phases. LH pulsatility was statistically different among the three phases $(p<0.001)$ representing normal ovulatory cycles. Conclusions: These data increase the knowledge about the testosterone secretion profile in the human menstrual cycle and can be used as a contribution to clinical investigation in both hyperandrogenism and androgen insufficiency syndrome. Arq Bras Endocrinol Metab. 2009;53(8):1040-6
\end{abstract}

Keywords

Testosterone; pulse; menstrual cycle

\section{RESUMO}

Objetivo: Avaliar o padrão pulsátil da secreção da testosterona em mulheres normais. Métodos: Oito mulheres saudáveis com ciclos ovulatórios foram selecionadas. Amostras sanguíneas foram coletadas a cada dez minutos durante seis horas, começando entre 7 e $8 \mathrm{~h}$ da manhã, após dez horas de jejum, nas três fases do ciclo menstrual: folicular média (Dia 7), folicular tardia (Dia 12) e lútea (Dia 21). Foram mensurados: testosterona, LH e, no basal, também SHBG. Resultados: A frequência dos pulsos de testosterona, média da amplitude do pulso, porcentagem do incremento da amplitude, duração e intervalos dos pulsos foram similares nas três fases $(p>0,05)$. A pulsatilidade do LH foi estatisticamente diferente entre as três fases ( $p<0,001$ ), caracterizando padrão característico do ciclo ovulatório normal. Conclusões: Esses dados aumentam o conhecimento sobre o padrão de secreção da testosterona no ciclo menstrual humano e representam uma contribuição para a investigação clínica, tanto no hiperandrogenismo como na síndrome de insuficiência androgênica. Arq Bras Endocrinol Metab. 2009;53(8):1040-6

Descritores

Testosterona; pulsatilidade; ciclo menstrual

\section{INTRODUCTION}

The women menstrual cycle involves a complex and 1 regular change in female anatomy and physiology, that occurs every month, between puberty and meno- pause, and results from the integrated function of the hypothalamus, pituitary, ovary and their effector's sites.

The ovarian steroidogenesis occurs at the granulosa and theca cells and varies according different phases of 
menstrual cycle. The hormone synthesis depends on several factors, such as gonadotrophin levels and its receptors, level of precursor substrate for steroidogenesis and presence of specific enzymes $(1,2)$. An essential factor for this regulation is the pulsatile pattern of gonadotrophin secretion by pituitary $(3,4)$.

Androgen synthesis by the ovaries occurs at the theca cells, and is mainly regulated by $\operatorname{LH}(5,6)$, but also by insulin $(7,8)$. These androgens are transferred to the preovulatory granulosa cells, where the androstenedione and testosterone are aromatized to estrone and estradiol by 17-b-hydroxysteroid dehydrogenase type I, stimulated by FSH (9). The ovarian androgen production and its conversion to estradiol are essential to the physiologic ovulatory process, and an insufficient androgen production at the follicular phase can lead to anovulation (10).

Some studies have shown fasting testosterone and androstenedione present some fluctuation in menstrual cycle with higher levels in follicular phase than in luteal phase, especially if cycles are ovulatory $(11,12)$. The majority of the hormones is synthesized and secreted in a pulsatile pattern. A pulse is identified by an abrupt increase with a subsequent decrease in the hormone output, which reflects in its serum concentration (13). Although normal pulsatility of androgen secretion was demonstrated in men $(14,15)$ as well as in some diseases (16), the normal pulsatile pattern of secretion and its variability among the different phases of the menstrual cycle have not been established yet.

An adequate androgen secretion is important to the follicle recruitment and selection but high androgenic levels can lead to anovulation (17) with changes in the pattern of secretion of gonadotrophins (18). Barontini and cols. (19) and Veldhuis and cols. (20) have suggested mechanism for pathogenesis of chronic anovulation and have shown disruption of the synchronous secretion of $\mathrm{LH}$ and testosterone in adolescents with polycystic ovary syndrome. Considering the related data and the actual facilities in prescribing testosterone for women by gynecologists, it is important to know if there is any variation of this hormone secretion on distinct phases of the normal menstrual cycle, enhancing the knowledge of the woman physiology. Thus, the aim of this study was to analyze the pulsatile secretion profile of testosterone in different phases of ovulatory menstrual cycle in healthy women.

\section{METHODS}

Eight young, healthy voluntary women were enrolled in this study. They were required to be between 18 and 30 years-old, non-smokers and with menstrual cycles occurring at regular intervals of 26 to 32 days. Menstrual cycles were considered as regular by menstrual recordings. The first day of menstrual bleeding was considered as the first day of the cycle. Ovulation was confirmed by serum progesterone level performed in the luteal phase $\left(21^{\text {st }}\right.$ day of the cycle) above $5.0 \mathrm{ng} / \mathrm{mL}(2 \mathrm{l})$ of each studied cycle. In the $21^{\text {st }}$ day of menstrual cycle, if progesterone levels were under $5.0 \mathrm{ng} / \mathrm{mL}$, the cycle was considered as anovulatory and discharged. Volunteers with history or evidence of heart, liver, or kidney disease, diabetes, menstrual or thyroid disorders, pregnancy, lactation and hypothalamic, pituitary or ovarian disorders were excluded. All patients who were on any drugs which could influence menstrual cycle during last three months were also excluded. The protocol of this experiment was approved by the Institutional Ethics Committee (UFRN), and all participants signed consent forms and received a full verbal and written description of the nature of the experiment, its risks and benefits and their ability to withdraw from the experiment at any time.

Volunteers were screened through interviews, and a clinical examination by a physician was performed before inclusion in the study. Body mass index (BMI) was calculated as weight $(\mathrm{kg})$ divided by the squared height $\left(\mathrm{m}^{2}\right)(22)$. All women were kept on dietary and exercise previous habits as well as used a barrier contraception method (condom) during the period of the study.

\section{Experimental data collection}

Considering the first day of menstrual cycle as Day 1 , blood samples were collected in three phases: mid-follicular $\left(7^{\text {th }}\right.$ day of the cycle or Day 7$)$, late follicular (Day 12) and mid-luteal phase (Day 21). Blood samples were collected in three consecutive cycles for each subject and hematocrits above $35 \%$ were required.

Blood samples were collected via a venous catheter at ten-minute intervals for six hours, starting between 7 and $8 \mathrm{am}$, after a ten-hour of fasting ( $\mathrm{n}=37$ points/subject). The subjects remained resting during the time of the experiment and were permitted to drink water or juice and to eat fruits at least every two hours. Blood sample were centrifuged and sera were stored at $-20^{\circ} \mathrm{C}$ until assayed.

\section{Hormone assays}

Samples collected at ten-minute intervals were assayed for testosterone and LH, and the first sample (baseline) was also assayed for SHBG. Total testosterone determination was performed by radioimmunoassay (RIA), 
with a "coat-a-count" kit (Diagnostic Products Corporation, Los Angeles, CA, USA), and LH and SHBG levels were performed with chemoluminescent kits at Immullite $^{\circledR} 2000$ equipment (Diagnostic Products Corporation, Los Angeles, CA, USA).

Method sensitivities for $\mathrm{LH}$, testosterone and SHBG were $0.05 \mathrm{mUI} / \mathrm{mL}, 4 \mathrm{ng} / \mathrm{dL}$, and $0.02 \mathrm{nmol} / \mathrm{L}$, respectively. Samples for each subject were done at the same assay to minimize the interassay variation. The intra-assay coefficients of variation for these assays were 3.8\% for the LH, $4.8 \%$ for testosterone, and $4.2 \%$ for SHBG.

Free androgen index (FAI) was calculated from total testosterone and SHBG: FAI $=(100 \mathrm{x}$ testosterone)/SHBG with both expressed in nanomoles per liter. FAI results were analyzed in the different phases of menstrual cycle. LH pulsatility was studied to confirm normal pattern of the studied cycles.

\section{Data analysis}

The time series of testosterone and LH concentrations over six hours were analyzed for mean concentration, pulse frequency, pulse amplitude, mean $\%$ amplitude elevation and pulse duration by the computer program Cluster, developed by Veldhuis and Johnson in 1986 at the University of Virginia. A $2 \times 1$ pulse configuration was used with up and down T-ratios of 2 to give a false detection rate less than $10 \%$.

\section{Statistical analysis}

Descriptive analysis was performed using GraphPad Prism, version 3.00 for Windows (GraphPad Software, San Diego, CA, USA). All data sets were tested for non-normality. One-way ANOVA and Kruskal-Wallis tests were performed to compare the three phases of menstrual cycle. P-value less than 0.05 was considered statistically significant.

\section{RESULTS}

Table 1 presents the characteristics of the subjects at the initial evaluation. Mean BMI was $21.33 \pm 0.97 \mathrm{~kg} / \mathrm{m}^{2}$ and all volunteers had ovulatory menstrual cycles.

Mean serum values of testosterone, LH, SHBG and FAI are shown in table 2 . There was no statistically significant difference in these parameters among the three menstrual cycle phases evaluated.

LH pulsatility was statistically different among the three phases of the menstrual cycle $(\mathrm{p}<0.001)$ with mean pulse frequency of $4.5 \pm 1.51$ in mid-follicular phase, $5.125 \pm 1.35$ in late follicular phase and $1.0 \pm$ 0.75 in luteal phase (Day 21) (Figure 1). Mean pulse interval was $66.39 \pm 15.19$ in mid-follicular phase, $60.00 \pm 17.43$ in late follicular phase and $100.00 \pm$ 102.50 in the luteal phase $(\mathrm{p}=0.02)$. There was no difference among the three phases in LH mean amplitude pulse, percentage of increment in pulse amplitude and mean duration of pulses (Figure 1).

Figure 2 illustrates serum testosterone pulsatile secretion profile in one of the eight ovulatory women, each of whom underwent repetitive blood sampling at ten-minute intervals in the mid-follicular (Day 7), late follicular (Day 12) and mid-luteal (Day 21) phase of menstrual cycle. Testosterone pulse frequency was similar in the three phases, with a mean of $5.25 \pm 0.70$ in the mid-follicular phase, $5.0 \pm 0.92$ in late follicular phase and $6.12 \pm 1.45$ in the luteal phase $(\mathrm{p}>0.05)$ (Figure 3 ). There was also no difference among the three phases in testosterone mean amplitude pulse, percentage of increment in pulse amplitude and mean duration of pulses (Figure 3). Mean frequency of testosterone nadir was 5.25 in the mid-follicular phase, 6.0 in late follicular phase and 6.25 in the luteal phase $(\mathrm{p}>0.05)$. There was no difference in pulse interval and in nadir duration among the three phases $(\mathrm{p}>0.05)$.

\section{DISCUSSION}

Ovarian function involves hormonal secretion, but also gametogenesis and ovulation. For this, a complex hormonal secretion and a coordinated relationship among

Table 1. Clinical, biochemical and hormonal characteristics of the subjects at the initial evaluation

\begin{tabular}{lccc}
\hline Characteristics & Mean & SD & Reference range \\
\hline Age (years) & 23.25 & 2.37 & - \\
Body mass index $\left(\mathrm{kg} / \mathrm{m}^{2}\right)$ & 21.33 & 0.97 & $20.00-24.99$ \\
Glucose $(\mathrm{mg} / \mathrm{dL})$ & 81.87 & 7.54 & $70.00-90.00$ \\
Urea $(\mathrm{mg} / \mathrm{dL})$ & 23.5 & 6.2 & $15.00-40.00$ \\
Creatinin $(\mathrm{mg} / \mathrm{dL})$ & 0.6 & 0.07 & $0.40-1.40$ \\
Aspartate aminotransferase $(\mathrm{U} / \mathrm{L})$ & 20.2 & 4.7 & $0.00-31.00$ \\
Alanine aminotransferase $(\mathrm{U} / \mathrm{L})$ & 19 & 6.5 & $0.00-31.00$ \\
Total protein $(\mathrm{g} / \mathrm{dL})$ & 6.8 & 0.4 & $6.00-8.00$ \\
Albumin $(\mathrm{g} / \mathrm{dL})$ & 4.1 & 0.3 & $4.00-6.00$ \\
Hematocrit $(\%)$ & 39.87 & 1.55 & $36.00-40.00$ \\
TSH (mUl/mL) & 2.23 & 1.3 & $0.4-4.0$ \\
Progesterone $(\mathrm{ng} / \mathrm{mL})^{*}$ & 12.38 & 4.17 & $>5.0$ \\
\hline
\end{tabular}

* Collected on the $21^{\text {st }}$ day of the menstrual cycle.

SD: standard deviation. 
hypothalamus, pituitary and ovary are necessary. The steroidal ovary production is also involved in this process.

Gonadotrophins have different pattern of secretion in men and women since the first day of life (23). Nevertheless, this difference remains in reproductive life with stable frequency and amplitude in men $(24,25)$, but shows great variability in women $(26,27)$, including ethnic variations (28). This gonadotrophin pulsatile liberation reflects the influence of the ovarian steroidal secretion on the hypothalamus pituitary axis.

Androgens are crucial factors for normal development of female gonadal function (10). There are suffi- cient data about gonadotrophin pulsatility $(27,29,30)$, but much less is seen about testosterone in the literature. In the present study, LH did show different pulse frequency from the studied phases as already registered by other authors $(26,27)$.

Healthy young females with ovulatory cycles have already been studied to evaluate testosterone pulsatility during the menstrual cycle. Multiple samples from each patient were collected: 111 samples, 37 in three menstrual cycles. There was no difference among the three phases in baseline testosterone nor in SHBG. FAI was calculated as a mean to analyze bioavailable testostero-

\begin{tabular}{|c|c|c|c|c|}
\hline Clinical characteristic & $\begin{array}{l}\text { Mid-follicular phase } \\
\quad(\text { mean } \pm \text { SD) }\end{array}$ & $\begin{array}{l}\text { Late follicular phase } \\
\quad(\text { mean } \pm \text { SD) }\end{array}$ & $\begin{array}{l}\text { Luteal phase } \\
\text { (mean } \pm \text { SD) }\end{array}$ & p-value \\
\hline $\mathrm{LH}(\mathrm{mUl} / \mathrm{mL})$ & $5.45 \pm 1.68$ & $6.90 \pm 1.62$ & $5.61 \pm 4.37$ & NS \\
\hline Testosterone (nmol/L) & $0.90 \pm 0.54$ & $1.34 \pm 0.47$ & $1.05 \pm 0.20$ & NS \\
\hline SHBG (nmol/L) & $42.45 \pm 16.23$ & $47.27 \pm 23.71$ & $46.81 \pm 15.61$ & NS \\
\hline $\mathrm{FAl}(\mathrm{nmol} / \mathrm{L})$ & $2.34 \pm 1.49$ & $3.19 \pm 1.40$ & $2.41 \pm 0.76$ & NS \\
\hline
\end{tabular}

SD: standard deviation; NS: non significant.
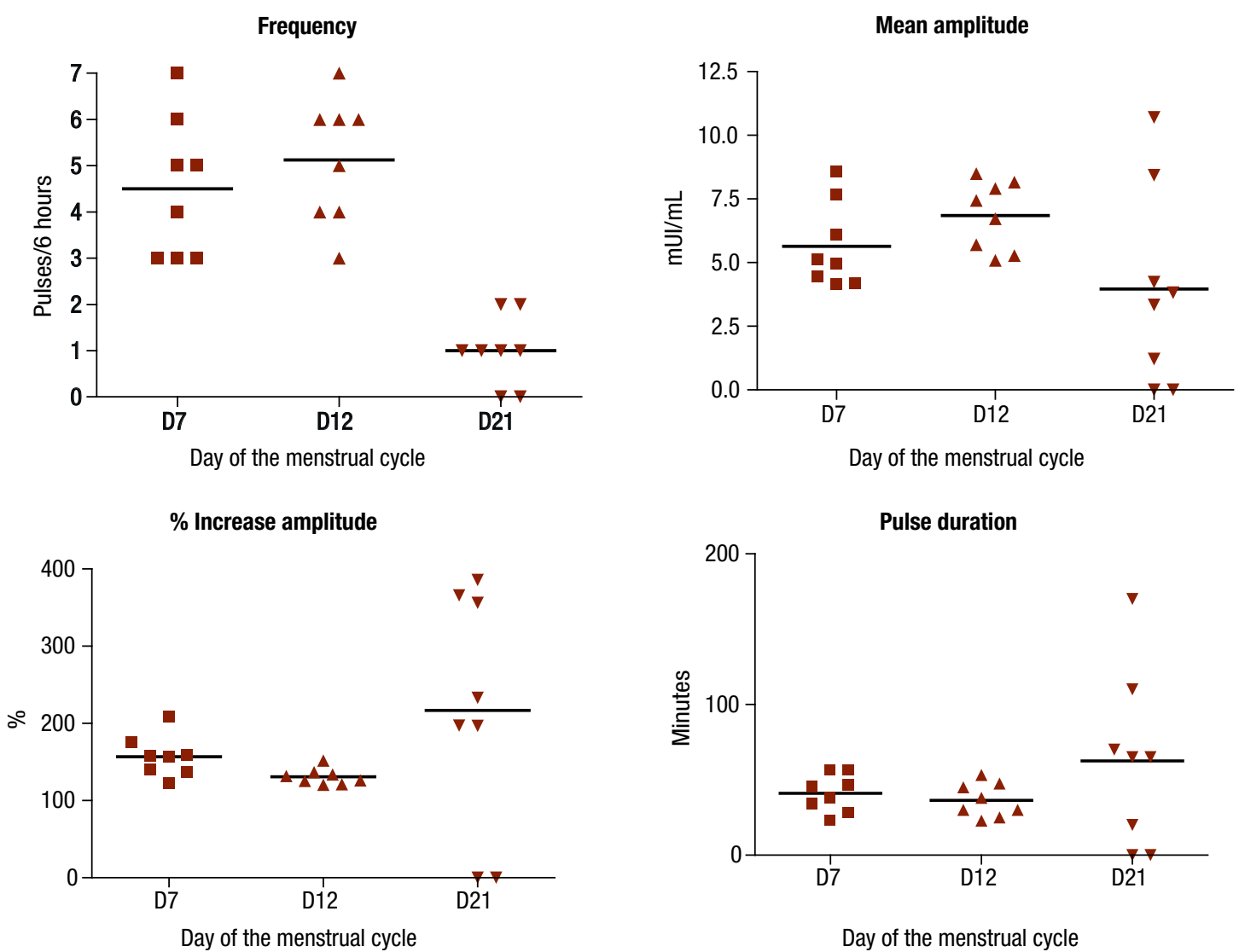

Figure 1. LH pulsatility in the three phases of the menstrual cycle. Frequency $(p<0.01)$ and mean amplitude $(p=0.02)$. Increase amplitude and pulse duration was not significant. 
ne (31), but it also did not show significant difference among the three phases.

By using adequate methodology, it has been shown that testosterone, as other hormones involved with re- productive physiology (27), is secreted in a pulsatile pattern. However, testosterone pulsatility pattern does not vary among the three different menstrual cycle phases studied: mid-follicular, late follicular and luteal phase.

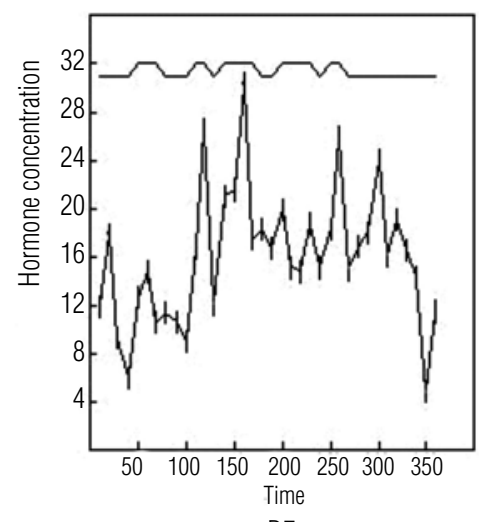

D7

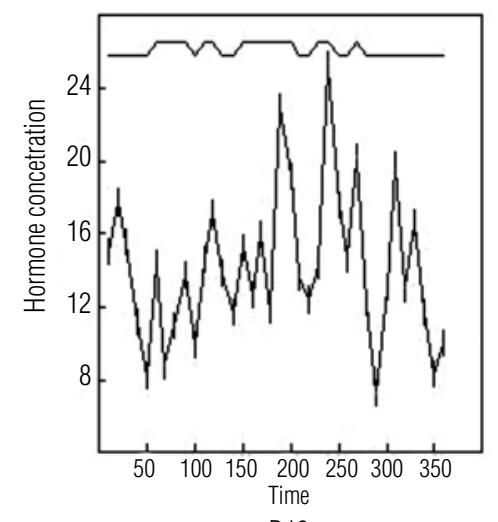

D12

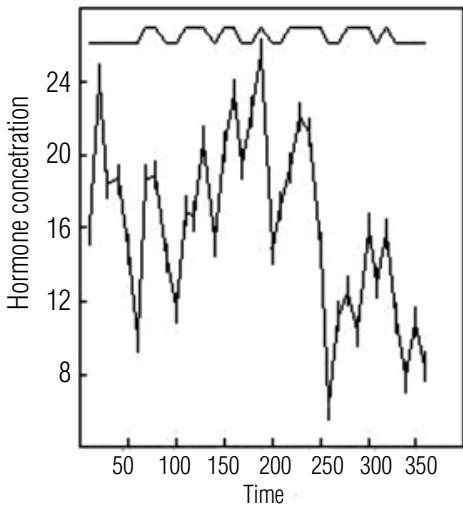

D21

Figure 2. Testosterone (ng/dL) pulsatility on Day 7, Day 12 and Day 21 of one of the eight subjects. Time expressed in minutes.

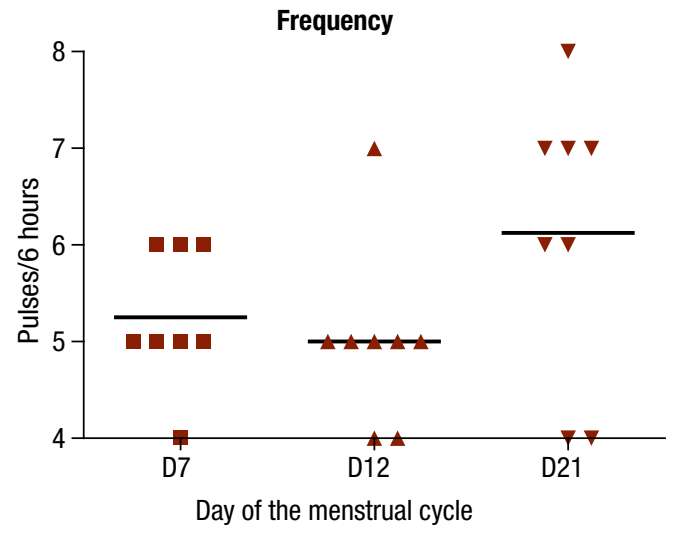

$\%$ Increase amplitude

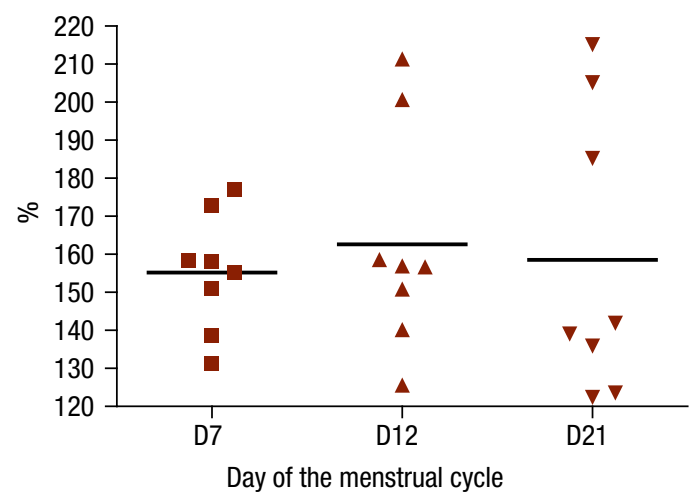

Mean amplitude

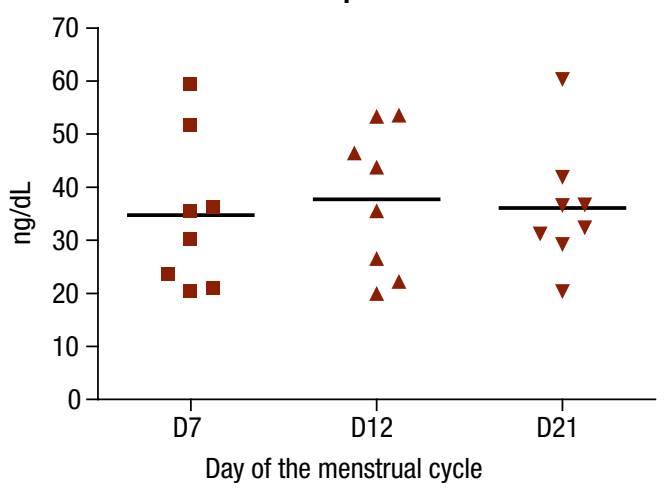

Pulse duration

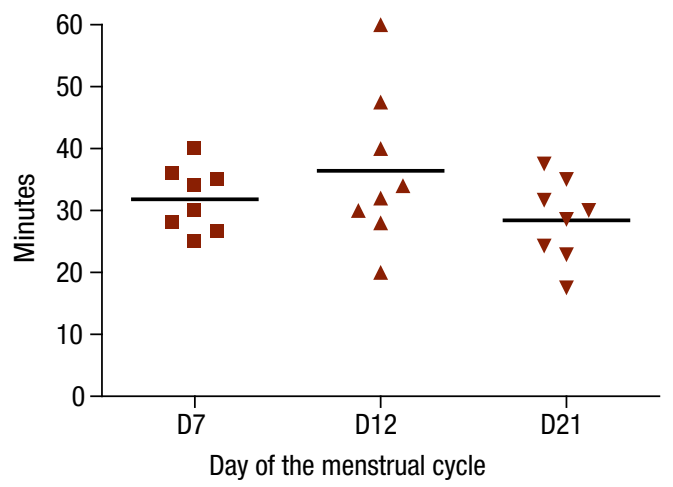

Figure 3. Testosterone pulsatility in the three phases of the menstrual cycle. No statistical significance in any parameter. 
It should be considered that, during the reproductive years, androgens are produced by two sources: ovaries and adrenal glands (32), and these are not under LH control. In addition, other hormones from ovary and adrenal, which production can vary during menstrual cycle, can influence in different ways the activated enzymatic mechanisms of the follicle and luteolysed cells and so could influence testosterone production beyond the $\mathrm{LH}(2)$.

Pulsatility studies are usually related to considerable difficulty in volunteer's recruitment. Multiple samples are required and total blood loss is a constant preoccupation $(20,33)$. The assay limitation is also important as testosterone assays are designed for higher levels presented in men and could not be accurate enough to determine lower women levels $(31,32)$. In addition, serum androgen levels do not necessarily reproduce intraovarian androgen concentrations. Further studies with assisted reproduction techniques could evaluate the correlation between intraovarian androgens and its serum pulsatility.

Variations in androgen levels or in its pulsatility could contribute to the understanding and management of some conditions related to androgen action, such as women mood and sexual behavior in the controversial androgen insufficiency syndrome which was characterized by a team of investigators in 2002 (34). It is well known that testosterone influence behavior and both cognitive and sexual function in men (35). However, evidence in women is limited by lack of normative data for androgen levels and much controversy relies about types of treatment. As sexual nor mood questionnaires were not used, comparison between androgen secretion pattern and possible behavior changes in menstrual cycle was not available.

It was shown that there is no variation in testosterone pulsatility during the normal menstrual cycle. This physiologic testosterone pulsatility could be compared to women with clinical features of the androgen insufficiency syndrome even if baseline androgen levels are still normal. Otherwise, testosterone normal pulsatility can also be compared to some hyperandrogenic states as the polycystic ovarian syndrome (PCOS). Peripheral conversion of androgen precursors to active androgens may play an important role in androgen action and this should influence states of hyperandrogenic diseases. It is shown that elevated androgen levels are associated with hyperandrogenic features, as acne and hirsutism, but there is no evidence to support a relationship be- tween the degree of androgen elevation and the severity of these clinical presentations (36). Sometimes, there is considerable discrepancy between androgen baseline levels and clinical presentation. Expression of androgens receptors in effector organs and hypersensibility of end-target organs are usually considered in these cases, but variations in testosterone pulsatility could explain women presented with hyperandrogenic features and normal baseline androgens.

In conclusion, this study presented, for the first time, that testosterone is secreted in a pulsatile pattern as well as the comparison of this pulsatile profile in distinct phases of the menstrual cycle without differences among them. Additional studies are needed to compare normal ovulatory cycles and pathologic cycles, both in androgen excess and androgen insufficiency, to define if there is any alteration in this pulsatile pattern related to hyperandrogenic anovulation or female androgen insufficiency syndrome.

Disclosure: no potential conflict of interest relevant to this article was reported.

\section{REFERENCES}

1. Suzuki T, Sasano H, Tamura M, Aoki H, Fukaya T, Yajima A, et al. Temporal and spatial localization of steroidogenic enzymes in premenopausal human ovaries: in situ hybridization and immunohistochemical study. Mol Cell Endocrinol. 1993;97(1-2):135-43.

2. Suzuki T, Sasano H, Kimura N, Tamura M, Fukaya T, Yajima A, et al. Immunohistochemical distribution of progesterone, androgen and oestrogen receptors in the human ovary during the menstrual cycle: relationship to expression of steroidogenic enzymes. Hum Reprod. 1994;9(9):1589-95.

3. Yen SS, Tsai CC, Naftolin F, Vandenberg G, Ajabor L. Pulsatile patterns of gonadotropin release in subjects with and without ovarian function. J Clin Endocrinol Metab. 1972;34(4):671-5.

4. Backstrom CT, McNeilly AS, Leask RM, Baird DT. Pulsatile secretion of $\mathrm{LH}, \mathrm{FSH}$, prolactin, oestradiol and progesterone during the human menstrual cycle. Clin Endocrinol (Oxf). 1982;17(1):29-42.

5. McNatty KP, Makris A, Osathanondh R, Ryan KJ. Effects of luteinizing hormone on steroidogenesis by thecal tissue from human ovarian follicles in vitro. Steroids. 1980;36(1):53-63.

6. Angelopoulos N, Goula A, Tolis G. The role of luteinizing hormone activity in controlled ovarian stimulation. J Endocrinol Invest. 2005;28(1):79-88.

7. Barbieri RL, Smith $\mathrm{S}$, Ryan KJ. The role of hyperinsulinemia in the pathogenesis of ovarian hyperandrogenism. Fertil Steril. 1988;50(2):197-212.

8. Tan S, Hahn S, Janssen OE. Insulin resistance syndrome and polycystic ovary syndrome: implications for diagnosis and treatment. Panminerva Med. 2005;47(4):211-7.

9. McNatty KP, Makris A, DeGrazia C, Osathanondh R, Ryan KJ. The production of progesterone, androgens, and estrogens by granulosa cells, thecal tissue, and stromal tissue from human ovaries in vitro. J Clin Endocrinol Metab. 1979;49(5):687-99. 
10. Haning RV Jr, Hackett RJ, Flood CA, Loughlin JS, Zhao QY, Longcope C. Testosterone, a follicular regulator: key to anovulation. J Clin Endocrinol Metab. 1993;77(3):710-5.

11. Goebelsmann U, Arce JJ, Thorneycroft IH, Mishell DR Jr. Serum testosterone concentrations in women throughout the menstrual cycle and following HCG administration. Am J Obstet Gynecol. 1974;119(4):445-52.

12. Ribeiro WO, Mishell DR Jr, Thorneycroft IH. Comparison of the patterns of androstenedione, progesterone, and estradiol during the human menstrual cycle. Am J Obstet Gynecol. 1974;119(8):1026-32.

13. Veldhuis JD, Keenan DM, Pincus SM. Motivations and methods for analyzing pulsatile hormone secretion. Endocr Rev. 2008;29(7):823-64.

14. Lejeune-Lenain C, Van Cauter E, Désir D, Beyloos M, Franckson JR. Control of circadian and episodic variations of adrenal androgens secretion in man. J Endocrinol Invest. 1987;10(3):267-76.

15. Gupta SK, Lindemulder EA, Sathyan G. Modeling of circadian testosterone in healthy men and hypogonadal men. J Clin Pharmacol. 2000;40(7):731-8.

16. Simoni M, Montanini V, Fustini MF, Del Rio G, Cioni K, Marrama P. Circadian rhythm of plasma testosterone in men with idiopathic hypogonadotrophic hypogonadism before and during pulsatile administration of gonadotrophin-releasing hormone. Clin Endocrinol (Oxf). 1992;36(1):29-34.

17. Ehrmann D. Polycystic ovary syndrome. $N$ Engl J Med. 2005;352(12):1223-36.

18. Venturoli S, Porcu E, Fabbri R, Magrini O, Gammi L, Paradisi R, et al. Episodic pulsatile secretion of FSH, LH, prolactin, oestradiol, oestrone, and LH circadian variations in polycystic ovary syndrome. Clin Endocrinol (Oxf). 1988;28(1):93-107.

19. Barontini M, Garcia-Rudaz MC, Veldhuis JD. Mechanisms of hypothalamic-pituitary-gonadal disruption in polycystic ovarian syndrome. Arch Med Res. 2001;32(6):544-52.

20. Veldhuis JD, Pincus SM, Garcia-Rudaz MC, Ropelato MG, Escobar $\mathrm{ME}$, Barontini M. Disruption of the joint synchrony of luteinizing hormone, testosterone, and androstenedione secretion in adolescents with polycystic ovarian syndrome. J Clin Endocrinol Metab. $2001 ; 86(1): 72-9$

21. Ahmad N, PollardTM, Unwin N. The optimal timing of blood collection during the menstrual cycle for the assessment of endogenous sex hormones: can interindividual differences in levels over the whole cycle be assessed on a single day? Cancer Epidemiol Biomarkers Prev. 2002;11(1):147-51.

22. Stavig GR, Leonard AR, Igra A, Felten P. Indices of relative body weight and ideal weight charts. J Chronic Dis. 1984;37(4):255-62.

23. de Zegher F, Devlieger H, Veldhuis JD. Pulsatile and sexually dimorphic secretion of luteinizing hormone in the human infant on the day of birth. Pediatr Res. 1992;32(5):605-7.

24. Partsch CJ, Abrahams S, Herholz N, Peter M, Veldhuis JD, Sippell WG. Variability of pulsatile luteinizing hormone secretion in young male volunteers. Eur J Endocrinol. 1994;131(3):263-72.

25. Veldhuis J. Pathophysiologic features of episodic gonadotropin secretion in man. Am J Med Sci. 1987;294(3):150-60.

26. Midgley AR Jr, Jaffe RB. Regulation of human gonadotropins. X. Episodic fluctuation of LH during the menstrual cycle. J Clin Endocrinol Metab. 1971;33(6):962-9.

27. Rossmanith WG. Ultradian and circadian patterns in luteinizing hormone secretion during reproductive life in women. Hum Reprod. 1993;8(Suppl 2):77-83.

28. Haiman CA, Pike MC, Bernstein L, Jaque SV, Stanczyk FZ, Afghani $A$, et al. Ethnic differences in ovulatory function in nulliparous women. Br J Cancer. 2002;86(3):367-71.

29. Grumbach MM. The neuroendocrinology of human puberty revisited. Horm Res. 2002;57(Suppl 2):2-14.

30. Knobil E. The neuroendocrine control of ovulation. Hum Reprod. 1988;3:469-72.

31. Vermeulen A, Verdonck L, Kaufman JM. A critical evaluation of simple methods for the estimation of free testosterone in serum. J Clin Endocrinol Metab. 1999;84(10):3666-72.

32. Davison SL, Davis SR. Androgens in women. J Steroid Biochem Mol Biol. 2003;85(2-5):363-6.

33. Veldhuis JD, Pincus SM, Garcia-Rudaz MC, Ropelato MG, Escobar $\mathrm{ME}$, Barontini M. Disruption of synchronous secretion of leptin, $\mathrm{LH}$ and ovarian androgens in nonobese adolescents with the polycystic ovarian syndrome. J Clin Endocrinol Metab. 2001;86(8):3772-8.

34. Bachmann G, Bancroft J, Braunstein G, Burger H, Davis S, Dennerstein $L$, et al. Female androgen insufficiency: the princeton consensus statement on definition, classification, and assessment. Fertil Steril. 2002;77(4):660-5.

35. Beauchet $\mathrm{O}$. Testosterone and cognitive function: current clinical evidence of a relationship. Eur J Endocrinol. 2006;155(6):773-81.

36. Shaw JC. Acne: effect of hormones on pathogenesis and management. Am J Clin Dermatol. 2002;3(8):571-8. 